Indonesian Journal of
Mathematics and Natural Sciences Education
p-ISSN:2721-172X e-ISSN: 2721-1746
Vol.1 No. 2 Th 2020; hal 121-129
http://mass.iain-jember.ac.id

\title{
Analisis Penalaran Adaptif Siswa dalam Memecahkan Masalah Matematika Berdasarkan Adversity Quotient (AQ)
}

\author{
Fatati Saniyyah $^{1, *}$, Illah Winiati Triyana ${ }^{1}$ \\ ${ }^{1}$ Program Studi Pendidikan Matematika, Universitas Qomaruddin. Gresik, Indonesia \\ *E-mail: retnotv@sinus.ac.id
}

\begin{abstract}
Abstrak
Penalaran adaptif merupakan salah satu keterampilan matematika yang perlu dikuasai siswa dalam pembelajaran di sekolah. Jika siswa memiliki penalaran adaptif yang baik, maka siswa lebih mudah dalam memecahkan masalah matematika. Dalam memecahkan masalah matematika, setiap siswa mempunyai respon yang berbeda-beda. Respon tersebut dinamakan Adversity Quotient (AQ). Penelitian ini bertujuan untuk mendeskripsikan penalaran adaptif siswa dalam memecahkan masalah matematika berdasarkan AQ. Jenis penelitian ini adalah deskriptif kualitatif dengan subjek penelitian sebanyak enam siswa. Metode pengumpulan data yang digunakan meliputi pemberian angket ARP (Adversity Response Profile) untuk mengelompokkan siswa berdasarkan tipe AQ, tes penalaran adaptif (TPA) untuk mengetahui penalaran adaptif siswa dalam memecahkan masalah matematika dan wawancara untuk memperoleh informasi yang lebih jelas terkait penalaran adaptif siswa. Adapun proses analisis data yang digunakan meliputi reduksi data, penyajian data dan penarikan kesimpulan. Hasil penelitian menunjukkan bahwa dalam memecahkan masalah matematika, siswa dengan AQ quitter hanya mampu memenuhi satu indikator penalaran adaptif yaitu menyusun dugaan. Siswa dengan AQ camper mampu memenuhi empat indikator penalaran adaptif yaitu menyusun dugaan, merencanakan dan menyelesaikan masalah matematika, menilai kebenaran jawaban dari suatu permasalahan serta memberikan jawaban dengan penarikan kesimpulan. Sedangkan siswa dengan AQ climber mampu memenuhi semua indikator penalaran adaptif, yaitu menyusun dugaan, merencanakan dan menyelesaikan masalah matematika, memberikan penjelasan terkait prosedur yang digunakan, menilai kebenaran jawaban dari suatu permasalahan serta memberikan jawaban dengan penarikan kesimpulan.
\end{abstract}

Kata Kunci: Penalaran Adaptif, Pemecahan Masalah Matematika, Adversity Quotient.

\section{PENDAHULUAN}

Matematika merupakan suatu ilmu pengetahuan yang mempunyai peran penting dalam tiap aspek kehidupan manusia. Sehingga tidak heran, jika matematika menjadi salah satu tolak ukur keberhasilan penyelenggaraan pendidikan di Indonesia. Hal tersebut dikarenakan di dalam pembelajaran matematika tidak hanya fokus pada hasil belajar saja, namun juga diajarkan tentang bagaimana cara meningkatkan kemampuan matematika, penalaran, pemecahan masalah, representasi matematis dan mengaitkan ide (NCTM, 2000). Berdasarkan tujuan 
pembelajaran matematika tersebut, maka pemecahan masalah dan penalaran merupakan sesuatu yang harus diajarkan guru pada siswa.

Jenis penalaran yang digunakan dalam penelitian ini adalah penalaran adaptif. Penalaran adaptif merupakan kemampuan berpikir logis untuk menarik kesimpulan dari suatu masalah dengan indikator-indikator tertentu (Wijajanti, 2011). Adapun indikator penalaran adaptif yang digunakan dalam penelitian ini disajikan pada tabel 1.

Tabel 1. Indikator Penalaran Adaptif dalam Memecahkan Masalah Matematika

\begin{tabular}{ll}
\hline No. & \multicolumn{1}{c}{ Indikator Penalaran adaptif } \\
\hline \multicolumn{1}{c}{$(1)$} & \multicolumn{1}{c}{$(2)$} \\
\hline 1. & Menyusun dugaan (conjecture) \\
2. & $\begin{array}{l}\text { Merencanakan dan } \\
\text { menyelesaikan masalah } \\
\text { matematika }\end{array}$ \\
3. & $\begin{array}{l}\text { Memberikan penjelasan terkait } \\
\text { prosedur yang digunakan }\end{array}$ \\
4. & $\begin{array}{l}\text { Menilai kebenaran jawaban dari } \\
\text { suatu permasalahan }\end{array}$ \\
5. & $\begin{array}{l}\text { Memberikan jawaban dengan } \\
\text { penarikan kesimpulan }\end{array}$ \\
\hline
\end{tabular}

Namun, berdasarkan pengamatan yang dilakukan oleh peneliti khususnya di SMP Negeri 1 Karangbinangun Lamongan kelas IX F, menunjukkan bahwa rata-rata kemampuan penalaran adaptif yang dimiliki siswa masih belum tercapai dengan optimal. Hal tersebut diperkuat dalam penelitian Indriani (2017) yang memberikan informasi bahwa penalaran adaptif siswa SMP dalam memecahkan masalah matematika masih dalam kategori sangat rendah. Padahal menurut National Research Council (NRC) menyatakan bahwa jika siswa memiliki penalaran adaptif yang baik, maka siswa akan lebih mudah belajar matematika terutama dalam memecahkan masalah matematika (Iriyanti dkk, 2017).

Setiap siswa mempunyai cara yang berbeda- beda dalam memecahkan masalah matematika. Artinya, siswa mempunyai respon individu yang berbeda-beda dalam menghadapi atau memecahkan masalah matematika. Respon individu tersebut dinamakan Adversity Quotient (AQ).

AQ yang dimiliki seseorang dibagi menjadi tiga tipe, yaitu quitter, camper, dan climber (Stoltz, 2000). Siswa dengan tipe quitter cenderung lebih menghindar dari suatu permasalahan. Siswa dengan tipe camper dalam menanggapi masalah mereka mempunyai kemauan dalam memecahkan masalah, tapi mereka tidak mau mengambil resiko. Artinya, dapat dikatakan bahwa siswa dengan tipe camper merasa puas dengan posisi tertentu. Sedangkan siswa yang bertipe climber mereka selalu siap menghadapi tantangan dan memahami apa yang ingin dicapai, siswa tersebut ingin terus meraih kesuksesan.

Siswa yang memiliki AQ tinggi maka dapat dikatakan bahwa siswa tersebut mampu menyelesaikan masalah dengan baik. Hal tersebut diperkuat dengan pendapat Stoltz (dalam Suhandoyo \& Wijayanti, 2016) yang mengatakan bahwa semakin tinggi AQ siswa, maka semakin baik pula seseorang dalam memecahkan masalah. Sehingga AQ merupakan salah satu hal yang mempengaruhi bagaimana siswa dalam memecahkan masalah terutama pada masalah matematika.

Berdasarkan latar belakang tersebut, maka peneliti melakukan pene- 
litian dengan judul "Analisis Penalaran Adaptif Siswa dalam Memecahkan Masalah Matematika Berdasarkan Adversity Quotient (AQ)". Adapun tujuan dari penelitian ini adalah untuk mendeskripsikan penalaran adaptif siswa yang memiliki AQ tipe quitter, camper dan climber dalam memecahkan masalah matematika.

\section{METODE}

Jenis penelitian ini adalah penelitian deskriptif kualitatif yang dilaksanakan di SMP Negeri 1 Karangbinangun Lamongan pada bulan Juli sampai Agustus semester ganjil tahun ajaran 2019/2020. Subjek dalam penelitian ini berjumlah enam siswa. Adapun pemilihan subjek tersebut menggunakan purposive sampling, yaitu subjek yang dipilih berdasarkan tipe AQ.

Teknik pengumpulan data pada penelitian ini menggunakan teknik angket ARP (Adversity Response Profile), tes penalaran adaptif (TPA) dan wawancara.

Pemberian angket ARP digunakan untuk mengelompokkan siswa ke dalam tipe $\mathrm{AQ}$ quitter $(<112)$, tipe $\mathrm{AQ}$ camper (112 - 175) dan tipe AQ climber (> 175). Peneliti menggunakan angket ARP yang dikembangkan oleh Stoltz dengan mengadopsi dari penelitian Pratiwi (2016) yang sudah teruji validitas dan reliabilitasnya. Kemudian dari masingmasing tipe AQ tersebut, dipilih dua siswa yang memiliki kemampuan matematika setara sebagai subjek penelitian.

Setelah subjek terpilih, diberikan TPA berupa suatu masalah matematika yang berkaitan dengan materi teorema Pythagoras yang sebelumnya divalidasi oleh dua validator. Tujuan dari TPA adalah untuk mengetahui penalaran adaptif siswa dalam memecahkan masalah tersebut. Sedangkan tujuan dari wawancara adalah untuk mencari dan memperjelas lebih dalam bagaimana penalaran adaptif siswa dalam memecahkan masalah jika terdapat kekurangan pada hasil TPA siswa.

Hasil dari TPA dan wawancara, kemudian dianalisis dengan menghubungkan indikator penalaran adaptif dalam memecahkan masalah matematika. Adapun analisis data yang dilakukan adalah reduksi data, penyajian data dan penarikan kesimpulan. Sebelum melakukan penarikan kesimpulan, maka data yang diperoleh diuji keabsahannya terlebih dahulu.

Uji keabsahan data yang digunakan dalam penelitian ini adalah uji kredibilitas dengan teknik pemeriksaan triangulasi sumber, yaitu dengan cara data yang diperoleh (hasil TPA dan wawancara) dari subjek pertama dibandingkan dengan subjek kedua dari masing-masing tipe AQ serta dilihat kesesuaiannya antara kedua sumber atau subjek tersebut.

Data yang diperoleh dari kedua subjek dari masing-masing tipe AQ tersebut dapat dikatakan kredibel jika hasil dari triangulasi tersebut saling bersesuaian dengan presentase kesesuaiannya $\geq 60 \%$ dari jumlah keseluruhan indikator penalaran adaptif (McHugh, 2012). Sedangkan jika presentase kesesuaiannya $<60 \%$ dari jumlah keseluruhan indikator penalaran adaptif, maka dibutuhkan sumber lain sampai ditemukan banyak kesamaan antara kedua subjek atau sumber dari masing-masing tipe AQ. 


\section{HASIL DAN PEMBAHASAN}

Berdasarkan metode penelitian yang sudah dijelaskan pada bagian sebelumnya, langkah pertama yang dilakukan dalam penelitian ini adalah pemberian angket ARP kepada 32 siswa kelas IX F, kemudian dari hasil skor ARP yang diperoleh dikelompokkan berdasarkan tipe-tipe AQ. Setelah itu, dari masing-masing tipe tersebut dipilih dua siswa yang memiliki kemampuan matematika setara untuk dijadikan subjek penelitian.

Hasil skor angket ARP dan kemampuan matematika setara, diperoleh siswa yang menjadi subjek penelitian seperti pada tabel 2.

Tabel 2. Daftar Subjek Penelitian

\begin{tabular}{cccc}
\hline $\begin{array}{c}\text { Kode } \\
\text { Siswa }\end{array}$ & Tipe AQ & $\begin{array}{c}\text { Skor } \\
\text { ARP }\end{array}$ & $\begin{array}{c}\text { Kode } \\
\text { Subjek }\end{array}$ \\
\hline$(1)$ & $(2)$ & $(3)$ & \\
\hline RHNW & Quitter & 104 & $\mathrm{~S}_{1}$ \\
LM & Quitter & 106 & $\mathrm{~S}_{2}$ \\
RDM & Quitter & 142 & $\mathrm{~S}_{3}$ \\
MKR & Quitter & 144 & $\mathrm{~S}_{4}$ \\
AAI & Climber & 198 & $\mathrm{~S}_{5}$ \\
APR & Climber & 201 & $\mathrm{~S}_{6}$ \\
\hline
\end{tabular}

Setelah subjek terpilih, langkah selanjutnya adalah pemberian TPA dan

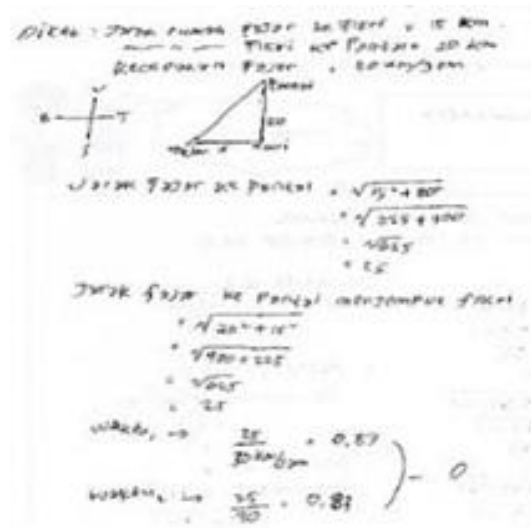

dan wawancara dari setiap subjek akan dideskripsikan sebagai berikut:

\section{Analisis Subjek Quitter}

Berdasarkan hasil jawaban TPA dan wawancara dalam memecahkan masalah matematika yang disajikan, menyatakan bahwa subjek quitter hanya mampu menyusun dugaan (conjecture). Subjek quitter tidak mampu merencanakan dan menyelesaikan masalah matematika, memberikan penjelasan terkait prosedur yang digunakan, menilai kebenaran jawaban dari suatu permasalahan serta memberikan jawaban dengan penarikan kesimpulan.

Akan tetapi, ketika menyusun dugaan (conjecture), S1 menuliskan informasi yang diketahui dengan menggambar serta menuliskan apa yang ditanyakan dalam permasalahan. Sedangkan S2 hanya menuliskan informasi yang diketahui dari permasalahan. Selain itu, subjek quitter tidak mampu merencanakan dan menyelesaiakan masalah matematika dikarenakan beberapa hal. S1 tidak mampu merencanakan dan menyelesaikan masalah matematika dikarenakan tidak dapat melanjutkan proses pengerjaannya. Sedangkan S2

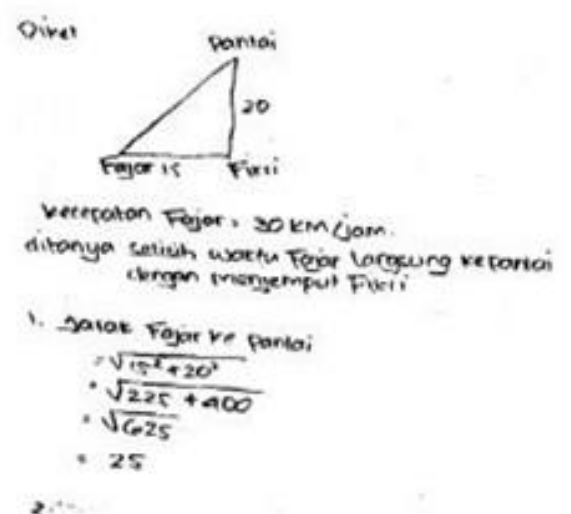

Gambar 1. Hasil Jawaban TPA $S_{1}$ dan $S_{2}$

melakukan wawancara terhadap subjek penelitian. Adapun hasil jawaban TPA tidak mampu merencanakan dan menyelesaikan masalah matematika di- 
karenakan konsep yang digunakan salah, sehingga hasil akhir yang diperoleh juga salah. Adapun hasil jawaban TPA dari subjek quitter akan disajikan pada gambar 1 .

Setelah data dideskripsikan dan dianalisis, maka dapat diketahui hasil triangulasi sumber yang menunjukkan bahwa kesesuaian antara S1 dan S2 dalam memecahkan masalah matematika mempunyai presentase kesesuaian $100 \%$, sehingga data yang diperoleh kredibel.

Berdasarkan hasil TPA dan wawancara, diketahui bahwa siswa yang memiliki AQ quitter tidak dapat memecahkan masalah matematika dengan penalaran adaptif yang baik, karena kedua siswa hanya memenuhi satu indikator penalaran adaptif, yaitu menyusun dugaan (conjecture) dengan menuliskan informasi yang diperoleh. Hal ini sejalan dengan hasil penelitian Pratiwi (2016) bahwa siswa dengan AQ quitter hanya mampu menuliskan informasi yang diperoleh dari masalah matematika yang disajikan.

Selain itu berdasarkan hasil wawancara, siswa dengan $\mathrm{AQ}$ quitter beranggapan bahwa masalah mate-

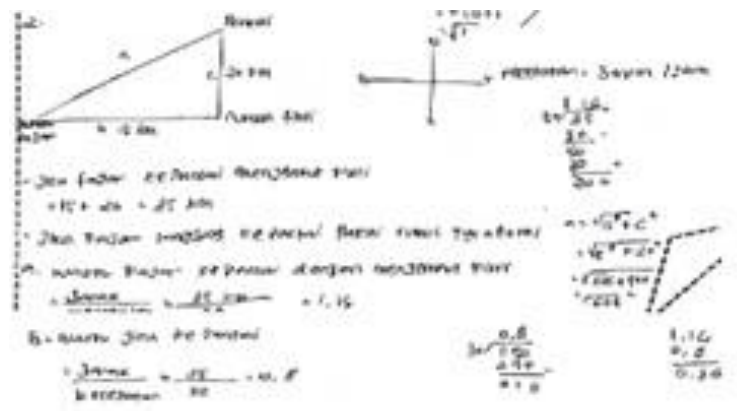

dan menjawab dengan seadanya dalam memecahkan masalah tanpa memaksimalkan penalaran mereka. Hal tersebut sesuai dengan teori Stoltz (2000) yang menyatakan bahwa siswa yang memiliki AQ quitter adalah siswa yang mudah putus asa, mudah menyerah dan tidak semangat untuk mencapai keberhasilan. Jadi siswa yang memiliki AQ quitter tidak memiliki motivasi untuk memecahkan suatu permasalahan, terutama dalam masalah matematika.

\section{Analisis Subjek Camper}

Berdasarkan hasil jawaban TPA dan wawancara dalam memecahkan masalah matematika yang disajikan, menyatakan bahwa subjek camper mampu menyusun dugaan (conjecture), merencanakan dan menyelesaikan masalah matematika, menilai kebenaran jawaban dari suatu permasalahan serta memberikan jawaban dengan penarikan kesimpulan. Subjek camper tidak mampu memberikan penjelasan terkait prosedur yang digunakan.

Akan tetapi, ketika menyusun dugaan (conjecture), $\mathrm{S}_{3}$ menuliskan informasi yang diketahui dengan memi-

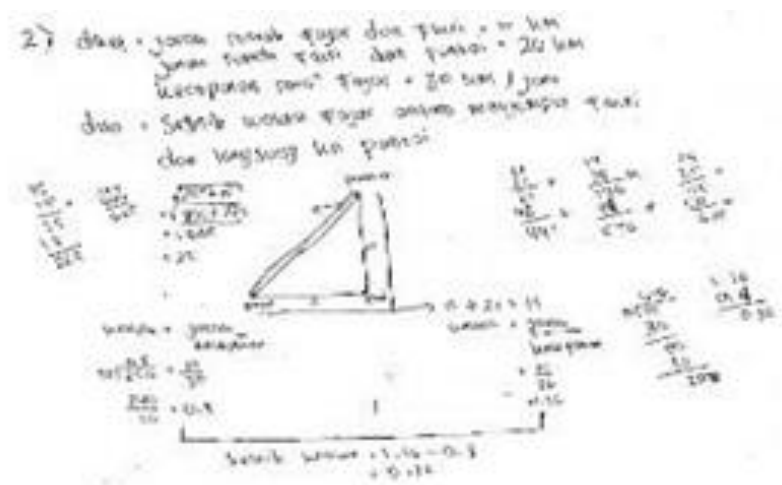

Gambar 2. Hasil Jawaban TPA $S_{3}$ dan $S_{4}$

matika yang disajikan itu sulit, sehingga kedua siswa mudah putus asa salkan dan membuat bentuk gambar segitiga yang disertai dengan angka- 
angka yang terdapat dalam permasalahan. Sedangkan S4 hanya menuliskan informasi yang diketahui dan ditanyakan dari permasalahan. Selain itu, ketika merencanakan dan menyelesaikan matematika, S3 merencanakan langkah-langkah dan menyelesaikan masalah dengan tepat hingga menemukan hasil akhirnya, yaitu 0,36 jam. Sedangkan S4 merencanakan dengan menggambar suatu permasalahan ke dalam bentuk segitiga yang disertai dengan angka-angka dan menyelesaikan perhitungan dengan tepat, sehingga hasil akhir yang diperoleh adalah 0,36. Adapun hasil jawaban TPA dari subjek camper akan disaji-kan pada gambar 2 .

Setelah data dideskripsikan dan dianalisis, maka dapat diketahui hasil triangulasi sumber yang menunjukkan bahwa kesesuaian antara $S_{3}$ dan $S_{4}$ dalam memecahkan masalah matematika mempunyai presentase kesesuaian $100 \%$, sehingga data yang diperoleh kredibel.

Berdasarkan hasil TPA dan wawancara, kedua siswa yang memiliki AQ camper mampu memenuhi empat dari lima indikator penalaran adaptif dalam memecahkan masalah. Kedua siswa tidak mampu memenuhi indikator dalam memberikan penjelasan terkait prosedur yang digunakan.

Dari hasil tersebut, dapat diketahui bahwa siswa dengan AQ camper memiliki penalaran adaptif yang lebih baik dari siswa dengan AQ quitter dalam memecahkan masalah matematika. Hal ini sesuai dengan pendapat Nababan dkk (2018) yang menyatakan bahwa siswa yang memiliki AQ camper memiliki penalaran adaptif yang cenderung lebih baik daripada siswa yang memiliki AQ quitter.

Berdasarkan hasil wawancara, siswa dengan AQ camper merasa kesulitan dalam memecahkan masalah matematika. Tetapi, mereka berusaha mencoba untuk menyelesaikan meskipun pada akhirnya mereka hanya puas pada hasil yang diperoleh. Hal tersebut sesuai dengan teori Stoltz (2000) yang menyatakan bahwa siswa dengan $\mathrm{AQ}$ camper adalah individu yang mudah puas dengan apa yang dicapainya. Dengan demikian, dapat diketahui bahwa siswa yang memiliki AQ camper kurang maksimal dalam penalarannya.

\section{Analisis Subjek Climber}

Berdasarkan hasil jawaban TPA dan wawancara dalam memecahkan masalah matematika yang disajikan, menyatakan bahwa subjek climber mampu menyusun dugaan (conjecture), merencanakan dan menyelesaikan masalah matematika, memberikan penjelasan terkait prosedur yang digunakan, menilai kebenaran jawaban dari suatu permasalahan serta memberikan jawaban dengan penarikan kesimpulan.

Akan tetapi, ketika menyusun dugaan (conjecture), $\mathrm{S}_{5}$ menuliskan informasi yang diketahui dan ditanyakan dalam permasalahan. Sedangkan $S_{6}$ menuliskan informasi yang diketahui dan ditanyakan dari permasalahan dengan membuat pemisalan. Selain itu, ketika merencanakan dan menyelesaikan matematika, $S_{5}$ merencanakan langkah-langkah untuk memecahkan masalah dengan menggambar permasalahan yang disajikan hingga menghitung selisih waktu yang dibutuhkan 
Fajar, yaitu 0,36 jam. Sedangkan $\mathrm{S}_{6}$ merencanakan dan menyelesaikan permasalahan secara terstruktur dan lengkap, sehingga hasil akhir yang diperoleh adalah 0,33 jam. Adapun hasil jawaban TPA dari subjek climber akan disajikan pada gambar 3 .

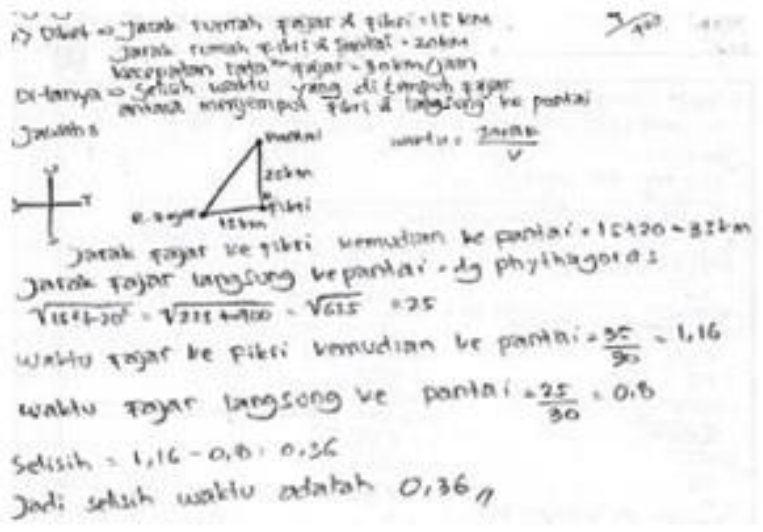

Gambar 2. Hasil Jawaban TPA $S_{3}$ dan $S_{4}$

Setelah data dideskripsikan dan dianalisis, maka dapat diketahui hasil triangulasi sumber yang menunjukkan bahwa kesesuaian antara $\mathrm{S}_{5}$ dan $\mathrm{S}_{6}$ dalam memecahkan masalah matematika mempunyai presentase kesesuaian $100 \%$, sehingga data yang diperoleh kredibel.

Berdasarkan hasil deskripsi dan analisis dari $S_{5}$ dan $S_{6}$ dapat disimpulkan bahwa siswa yang memiliki AQ climber dapat memecahkan masalah matematika dengan baik karena memenuhi semua indikator penalaran adaptif.

Dari hasil TPA dan wawancara, siswa dengan AQ climber memiliki penalaran adaptif yang lebih baik di antara siswa yang memiliki AQ camper dan quitter, karena siswa yang memiliki AQ climber memenuhi semua dari indikator penalaran adaptif dengan baik. Hal ini sejalan dengan penelitian Budiarti (2018) menjelaskan bahwa semakin tinggi kecerdasan siswa maka semakin baik pula pola pikir dan mampu meningkatkan kemampuan berpikirnya, salah satunya adalah penalaran dan memecahkan masalah matematika. Selama siswa yang memiliki AQ climber melakukan proses pemecahan masalah terkait penalaran adaptif, siswa terus berusaha untuk

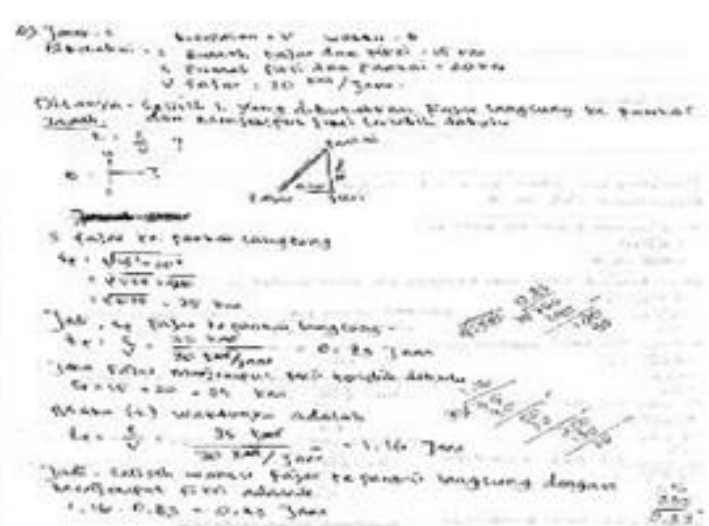

memecahkan masalah yang disajikan. Jika siswa mengalami kendala dalam memecahkan masalah, siswa tidak pernah putus asa dan selalu berusaha untuk mendapatkan jawaban yang sesuai dengan apa yang direncanakan. Sehingga siswa dengan AQ climber mendapatkan hasil yang terbaik dalam memecahkan masalah yang disajikan. Hal ini sesuai dengan teori Stoltz (2000) yang menyatakan bahwa siswa yang bertipe AQ climber adalah tipe dari siswa yang selalu berusaha mencapai puncak kesuksesan dan siap menghadapi rintangan yang ada. Siswa dengan AQ climber selalu memiliki motivasi untuk mencapai suatu target yang ingin dicapai.

\section{SIMPULAN}

Berdasarkan hasil analisis data dan pembahasan yang telah dijelaskan pada bab sebelumnya, maka simpulan yang diperoleh adalah:

(1) Siswa yang memiliki AQ quitter hanya memenuhi satu dari lima indikator 
penalaran adptif. Oleh karena itu, dapat dikatakan bahwa siswa dengan AQ quitter tidak menunjukkan sikap positif dalam memecahkan masalah, karena siswa dengan AQ quitter cenderung menyerah dalam memecahkan suatu masalah terutama masalah matematika; (2) Siswa yang memiliki AQ camper mampu memenuhi empat dari lima indikator penalaran adaptif. Oleh karena itu, dapat dikatakan bahwa siswa dengan AQ camper memiliki suatu usaha agar dapat memecahkan masalah matematika, akan tetapi mereka merasa cepat puas dengan apa yang sudah dicapainya; (3) Siswa yang memiliki AQ climber mampu memenuhi semua indikator penalaran adaptif. Oleh karena itu, dapat dikatakan bahwa siswa AQ climber selalu memiliki motivasi untuk mencapai sesuatu yang ingin dicapai. Siswa selalu berusaha menemukan jawaban yang sesuai dengan apa yang direncanakan.

\section{DAFTAR PUSTAKA}

Budiarti, N. O. (2018). Profil Penalaran Adaptif dan Disposisi Produktif Siswa dalam Menyelesaikan Masalah Matematika Ditinjau Dari Kecerdasan Emosional. Skripsi. Universitas Islam Negeri Sunan Ampel Surabaya.

Indriani, T. (2017). Kemampuan Penalaran Adaptif Siswa dalam Memecahkan Masalah Kelas VIII SMP Pontianak. Skripsi. Universitas Tanjungpura.

Iriyanti, R., Haji, S., \& Zamzaili. (2017). Kemampuan Pemahaman Konsep dan Penalaran Adaptif pada Siswa Kelas VIII SMP Negeri 2 Lubuk Linggau yang diajar Melalui Pendekatan Pembelajaran Matematika Realistic dengan Tipe Structure Dyadic Method. Jurnal
Pendidikan Matematika. 2 (1): 65-82.

McHugh, M. L. (2012). Interrater Reliability: The Kappa Statistic. Biochemia Medica, 276-282.

Nababan, R. J., Sutriyono, \& Pratama, F. W. 2009. Analisis Kemampuan Pemecahan Masalah Matematika Siswa SMP Berdasarkan Tahapan Polya Ditinjau dari Adversity Quotient . Jurnal Pemikiran dan Penelitian Pendidikan Matematika. 5 (4): 80-92.

NCTM. (2000). Principles and Standards for School Mathematics. Reston, VA: NCTM.

Pratiwi, Y. C. (2016). Analisis Kemampuan Pemecahan Masalah Matematika Siswa SMP dalam Pembelajaran Creative Problem Solving Ditinjau dari Adversity Quotient. Skripsi. Universitas Negeri Semarang.

Stoltz. (2000). Adversity Quotient, Mengubah Hambatan Menjadi Peluang. (Terjemahan oleh $T$ Hermaya). Jakarta: PT Gramedia Widiasarana Indonesia.

Suhandoyo, G., \& Wijayanti, P. (2016). Profil Kemampuan Berpikir Kreatif Siswa dalam Menyelesaikan Soal Higher Order Thinking Ditinjau dari Adversity Quotient (AQ). Jurnal Ilmiah Pendidikan Matematika. 3 (5): 156165.

Wijajanti, D. B. (2011). Mengembangkan Kecakapan Matematis Mahasiswa Calon Guru Matematika Melalui Strategi Perkuliahan Kolaboratif Berbasis Masalah. Prosiding 
Seminar Nasional Penelitian, Pendidikan terakhir sarjana PenPendidikan dan Penerapan, 151-158. didikan Matematika di Universitas

\section{PROFIL SINGKAT} Qomaruddin Gresik yang lulus pada

Nama Fatati Saniyyah, lahir pada tanggal 26 Juni 1997 di Lamongan. tahun 2019. 